\title{
Combination of Vacuum Packaging and Cold Storage "Urutan" Chicken to Extend Shelf Life
}

\author{
A.A. Made Semariyani ${ }^{*}$, I Wayan Sudiarta ${ }^{2}$ \\ ${ }^{1,2}$ Food Science and Technology Department, Faculty of Agriculture, Universitas Warmadewa, \\ Denpasar, Bali-Indonesia \\ \{asemariyani@gmail.com ${ }^{1}$ \}
}

\begin{abstract}
Urutan" is a product from home industries that are produced in all parts of Bali. The research method used is an experimental method. The research started from making a "urutan" of chickens using Appropriate Technology that had been obtained from previous research. "Urutan" is vacuum packed and stored at temperature $(10 \pm$ 1)oC. Analysis during product storage objectively includes moisture content, protein content, fat content, ash content, total plate count and E.coli and the subjective analysis (overall acceptance) is carried out every 10 days. Data analysis used ANOVA with Duncant's advanced test. The results obtained will be compared with the SNI for Meat Sausage (SNI 01-3820-2015). From the research results, it was found that all the parameters tested met the SNI requirements for meat sausage (SNI 3820-01-2015), only free fatty acids increased during storage, but in SNI it does not require a maximum limit of free fatty acids, but the presence of free fatty acids in products food indicates that the product has experienced quality deterioration. The treatment of vacuum packaging and cold storage can extend the shelf life of the Urutan to 30 days with the following characteristics: moisture content of $51.763 \%$, ash content $1.703 \%$, fat content 7,862 , protein content 29,626 , and carbohydrates content $7,212 \%$, free fatty acids $1,834 \%$, normal color, normal aroma, round texture length, normal taste, Total Microbial 640 colonies/g, and bacteria Escerisia coli $<3$ AMP / g only free fatty acids have increased during storage, but SNI does not require a maximum limit of free fatty acids, however, the presence of free fatty acids in food products indicates that the product has deteriorated quality. The treatment of vacuum packaging and cold storage can extend the shelf life of the Urutan to 30 days with the following characteristics: moisture content of $51.763 \%$, ash $1.703 \%$, fat 7,862 , protein 29,626 , carbohydrates $7,212 \%$, free fatty acids $1,834 \%$, normal color, normal aroma, round texture length, normal taste, Total Microbial 640 colonies / g, and bacteria Escerisia coli <3 AMP / g only free fatty acids have increased during storage, but SNI does not require a maximum limit of free fatty acids, however, the presence of free fatty acids in food products indicates that the product has deteriorated quality. The treatment of vacuum packaging and cold storage can extend the shelf life of the urutan to 30 days with the following characteristics: moisture content of $51.763 \%$, ash $1.703 \%$, fat 7,862 , protein 29,626 , carbohydrates $7,212 \%$, free fatty acids $1,834 \%$, normal color, normal aroma, round texture length, normal taste, Total Microbial 640 colonies/g, and bacteria Escerisia coli $<3$ AMP/
\end{abstract}

Keywords: Chicken "Urutan"; Vacuum Packaging; Cold Storage; Shelf Life 


\section{Introduction}

One of the efforts to increase the competitiveness of traditional food products is to improve quality and increase food safety. Processors should be taught to understand the basic principles of correct processing so that product quality assurance can be applied. Quality and quality assurance are part of modern life, therefore it must be implemented even though it is still a traditional processing industry. If this is not done, it is likely that traditional products can be abandoned because food safety is not guaranteed. For processed meat products, especially chicken "Urutan" is feared to be easily damaged because sales are not properly packaged and storage is also carried out at room temperature (without refrigeration) .

Urutan is one of the traditional Balinese food products, a kind of sausage, which is made through a fermentation process, apart from bebontot, buntilan, takilan wild boar, brem, tuak and arak [1] [2]. The "Urutan" quality of the chicken is very much determined by the raw materials (chicken meat and chicken fat) the use of the types of spices, the steaming and frying process and the supporting actions, namely using clean equipment, proper packaging and storage methods. Processors of chicken "Urutan" in producing chicken "Urutans" do not use measured spices, do not add fat, steaming and frying time is only based on experience so that the quality is less favorable in terms of texture (still hard texture).

After the research was carried out in 2017, the Appropriate Technology was obtained in making "Urutan" of chickens with good quality, namely the addition of $10 \%$ fat without the fermentation process. Urutan is one of the food products which has perishable characteristics so that it needs proper packaging and storage to extend its shelf life [3]. Thus, the unanswered problem for chicken "Urutan" processing is the problem of proper packaging materials used to store chicken "Urutans" in cold temperatures so that they can be stored for a relatively longer period of time but still have good quality and are preferred by consumers.

For this problem, the researcher will conduct research to store the "Urutan" of chickens produced with Appropriate Technology with vacuum packaging techniques and cold storage $(10 \pm 1)$ oC to extend the shelf life of the "Urutan" Chicken.

\section{Method}

\subsection{Location and Length of Research}

The research was carried out at the Processing Laboratory of the Faculty of Agriculture, Warmadewa University as a place to make "Urutan" of chickens and store them and carry out Microbiological analysis (TPC), E. coli, analysis of moisture content, analysis of fat, carbohydrate content, and ash content. Laboratory of Food Analysis, Faculty of Agricultural Technology, Udayana University for chemical analysis (protein analysis). The research period was 8 months starting from product manufacture (according to the appropriate technology in previous research), vacuum packaging, cold storage $(10 \pm 1) \mathrm{oC}$ and shelf life analysis.

\subsection{Research Methods}

This research is using experimental method. In this study, the "Urutan" of chickens was made using the best formula from previous studies, namely the addition of $10 \%$ fat without the fermentation process. The "Urutan" is vacuum packed and stored at temperature (10 \pm 1$)$, observations on storage $0,10,20,30,40,50$ day. 


\subsection{Materials and Tools}

The ingredients used are the "Urutan" of chicken, a set of chemicals used for TPC (Total Plate Count) analysis, E coli, Fat Content Analysis, Protein Content, Water Content, Carbohydrate Content, Ash Content, such as: Nutrient agar, Pepton , Aquades, Petrolium Ether, $\mathrm{H}_{2} \mathrm{SO}_{4}$, cotton, tissue paper, alcohol, spirits and materials for organoleptic tests.

Equipment used in the manufacture of chicken "Urutans", namely cutting boards, knives, scales, blenders, steamer, pans, spoons, cassings, threads, and equipment for microbiological analysis, chemical analysis including: Autoclave, Laminar flow, Petri dish, erlenmeyer, test tubes, pipettes, a set of Soxlets for fat analysis, sample plates, desiccators, conway plates and equipment for organoleptic tests (plates, spoons, labels, questionnaires / assessment blanks).

\subsection{Observed variables}

Analysis during product storage includes subjective analysis (hedonic test), objective tests include Fat Content, Protein Content, Water Content, Carbohydrate Content, Ash Content [4], total microbes and E coli (BAM, 2001). Organoleptic Analysis with Sensory Test [5].

\subsection{Statistic analysis}

The data obtained from this study were analyzed quantitatively with the analysis of variance (ANOVA). If the data obtained shows a significant difference, then proceed with the Duncans Multiple Range Test (DMRT). Statistical analysis with the help of SPSS software for windows versions 22 of 2015 . The data obtained were also analyzed descriptively and the data were also displayed with tables, pictures and graphs.

\section{Results and Discussion}

\subsection{Objective Variables}

Based on the results of the analysis of variance on the moisture content of the chicken Urutan, it showed that the interaction of vacuum packaging and cold storage treatment had no significant effect $(\mathrm{P} \geq 0.05)$, as well as the treatment of vacuum packaging and cold storage had no significant effect $((\mathrm{P} \geq 0,05)$ for all parameters of chicken "Urutan" test The average values of water content, ash content, fat content, protein content and carbohydrate content of chicken "Urutan" can be seen in Table 1.

Table 1. Average Value of Water Content, Ash Content, Fat Content, Protein and Carbohydrate Content of "Urutan" Chicken (\%)

\begin{tabular}{cccccccccc}
\hline Treatment & Water content & & Ash content & & Fat content & \multicolumn{2}{c}{$\begin{array}{c}\text { Protein } \\
\text { Content }\end{array}$} & \multicolumn{2}{c}{ KH levels } \\
\hline VIP0 & 52,520 & $\mathrm{a}$ & 1,793 & $\mathrm{a}$ & $7,690 \mathrm{a}$ & 28,921 & $\mathrm{a}$ & 7,373 & $\mathrm{a}$ \\
VIP1 & 52,385 & $\mathrm{a}$ & 1,944 & $\mathrm{a}$ & $8,160 \mathrm{a}$ & 29,045 & $\mathrm{a}$ & 6,701 & $\mathrm{a}$ \\
VIP2 & 52,051 & $\mathrm{a}$ & 1,832 & $\mathrm{a}$ & $8,692 \mathrm{a}$ & 28,427 & $\mathrm{a}$ & 7,182 & $\mathrm{a}$ \\
VIP3 & 51,763 & $\mathrm{a}$ & 1,703 & $\mathrm{a}$ & $7,862 \mathrm{a}$ & 29,626 & $\mathrm{a}$ & 7,212 & $\mathrm{a}$ \\
VIP4 & 51,169 & $\mathrm{a}$ & 1,892 & $\mathrm{a}$ & $6,966 \mathrm{a}$ & 28,701 & $\mathrm{a}$ & 9,387 & $\mathrm{a}$ \\
VIP5 & 51,286 & $\mathrm{a}$ & 1,876 & $\mathrm{a}$ & $7,229 \mathrm{a}$ & 27,631 & $\mathrm{a}$ & 9,943 & $\mathrm{a}$ \\
V2P0 & 52,947 & $\mathrm{a}$ & 1,711 & $\mathrm{a}$ & $7,179 \mathrm{a}$ & 29,105 & $\mathrm{a}$ & 7,275 & $\mathrm{a}$ \\
V2P1 & 53,026 & $\mathrm{a}$ & 1,667 & $\mathrm{a}$ & $10,389 \mathrm{a}$ & 25,908 & $\mathrm{a}$ & 6,998 & $\mathrm{a}$ \\
V2P2 & 53,053 & $\mathrm{a}$ & 2,006 & $\mathrm{a}$ & $8,503 \mathrm{a}$ & 27,454 & $\mathrm{a}$ & 6,946 & $\mathrm{a}$ \\
\hline
\end{tabular}




\begin{tabular}{llllllllll}
\hline V2P3 & 49,678 & $\mathrm{a}$ & 1,421 & $\mathrm{a}$ & $7,842 \mathrm{a}$ & 31,970 & $\mathrm{a}$ & 7,059 & $\mathrm{a}$ \\
V2P4 & 50,173 & $\mathrm{a}$ & 1,912 & $\mathrm{a}$ & $8,550 \mathrm{a}$ & 28,738 & $\mathrm{a}$ & 8,504 & $\mathrm{a}$ \\
V2P5 & 50,422 & $\mathrm{a}$ & 1,936 & $\mathrm{a}$ & $8,264 \mathrm{a}$ & 29,983 & $\mathrm{a}$ & 7,132 & $\mathrm{a}$ \\
\hline
\end{tabular}

Note: The average value followed by the same letter in the same column shows an insignificant difference.

From Table 1, it can be seen that the moisture content of the "Urutan" of chickens due to vacuum packaging and cold storage treatments ranged from $49.678 \%$ to $53.053 \%$. The lowest water content of "Urutan" chickens was obtained from the treatment of non-vacuum packaging with 30 days of storage (V2P3), which was $49.678 \%$, while the highest was obtained in the non-vacuum packaging treatment at 20 days (V2P2) of $53.053 \%$. There was a decrease in water content during cold storage, both in the vacuum packed and non-vacuum packed Urutan, in the vacuum packaged the decrease in water content was lower than those that were not vacuumed, this was due to the fact that in the vacuum condition water vapor could not get out of the package so that it remained in the packaging / material.

The results showed that the interaction between vacuum packaging and cold storage, packaging and cold storage treatments had no significant effect $(\mathrm{P} \geq 0.05)$ on the ash content of "Urutan" chickens. The average value of the ash content of the chicken Urutans ranged from $1.667 \% \mathrm{w} / \mathrm{w}$ to $2.006 \% \mathrm{w} / \mathrm{w}$. The lowest ash content was obtained in the non-vacuum packaging treatment with a storage time of 10 days, namely $1.667 \%$, while the highest was obtained in the long-time without vacuum packaging treatment when compared to the standard chemical composition of meat sausage (SNI 01-3820-2015) which requires a maximum ash content of $3 \%$ then all treatments meet the standard.

The results showed that the interaction between vacuum packaging and cold storage, packaging and cold storage treatments had no significant effect $(\mathrm{P} \geq 0.05)$ on the "Urutan" fat content of chickens. The average value of the lowest "Urutan" fat content of chickens was obtained from the vacuum packaging treatment with cold storage for 40 days (V1P4), which was $6.966 \%$, while the highest fat content was obtained from non-vacuum packaging treatment and cold storage for 10 days (V2P1). which is equal to $10.389 \%$. The "Urutan" fat content of chicken obtained from the results of this study when compared with the standard chemical composition of meat sausages (SNI 01-3820-2015) all fulfills the requirements because all fat content is below the required standard, namely a maximum of $20 \% \mathrm{w} / \mathrm{w}$.

The results showed that the interaction between vacuum packaging and cold storage and vacuum packaging and cold storage treatments had no significant effect $(\mathrm{P} \geq 0.05)$ on chicken "Urutan" protein content. The mean value of chicken "Urutan" protein content ranged from 6.701 to $9.943 \%$. The average value of the lowest "Urutan" protein content of chickens was obtained from the non-vacuum packaging treatment with cold storage for 10 days (V2P1), which was $25.908 \%$, while the highest protein content was obtained from the non-vacuum packaging treatment and cold storage time for 30 days (V1P5) which is $31,970 \%$.

The results showed that the interaction between vacuum packaging and cold storage, packaging and cold storage treatments had no significant effect $(\mathrm{P} \geq 0.05)$ on chicken "Urutan" carbohydrate content. The average value of the lowest "Urutan" carbohydrate content of chickens was obtained from the vacuum packaging treatment with cold storage for 10 days (V1P1) which was $6.701 \%$, while the highest carbohydrate content was obtained from the vacuum packaging treatment and cold storage time for 50 days (V2P1), namely amounted to $9.943 \%$

The results showed that the interaction between vacuum packaging and cold storage had no significant effect $(\mathrm{P} \geq 0.05)$, while the packaging treatment and cold storage treatment had a 
significant effect $(\mathrm{P}<05)$ on the levels of free fatty acid (ALB) "Urutan" of chickens. The average value of the lowest "Urutan" fat content of chickens was obtained from the vacuum packaging treatment with cold storage for 40 days (V1P4), which was $6.966 \%$, while the highest fat content was obtained from non-vacuum packaging treatment and cold storage for 10 days (V2P1). which is equal to $10.389 \%$.

\subsection{Subjective Variables}

Based on the results of statistical analysis, the color, texture and overall variables showed no significant effect $(\mathrm{P} \geq 0.05)$ on the treatment of chicken Urutans. Meanwhile, the taste variable showed a significantly different effect $(\mathrm{P}<0.05)$ on the Urutan of the chicken and the aroma variable showed a very significant difference $(\mathrm{P}<0.01)$. The average value of the panelists' acceptance level towards subjective observations is presented in Table 2.

Table 2. Organoleptic "Urutan" Test Results for Chickens Due to Vacuum Packaging and Cold Storage Treatment

\begin{tabular}{cclll}
\hline Treatment & Color & Aroma & Texture & Taste \\
\hline VIP0 & Normal & Normal & Long Round & Normal \\
VIP1 & Normal & Normal & Long Round & Normal \\
VIP2 & Normal & Normal & Long Round & Normal \\
VIP3 & Normal & Normal & Long Round & Normal \\
VIP4 & Normal & Normal & Long Round & Normal \\
VIP5 & Normal & Normal & Long Round & Normal \\
V2P0 & Normal & Normal & Long Round & Normal \\
V2P1 & Normal & Normal & Long Round & Normal \\
V2P2 & Normal & Normal & Long Round & Normal \\
V2P3 & Normal & Normal & Long Round & Normal \\
V2P4 & Normal & Normal & Long Round & Normal \\
V2P5 & Normal & Normal & Long Round & Normal \\
\hline
\end{tabular}

From the results of the organoleptic data analysis, it was found that the treatment of vacuum packaging and cold storage did not significantly affect the color of the 'Urutan' of chickens during storage. The assessment of 15 panelists stated that the color of the chicken Urutan until 50 days of storage was still normal, namely yellowish brown, this color was obtained because there was a frying process.

Color is the first parameter seen by consumers, so this parameter can be the first reference used by consumers in assessing the quality of a food product. Color has an important role in assessing a food product that can increase consumer taste. A food product that is considered nutritious, delicious and with a very good texture will not be eaten if it has an unsightly color or gives an impression that deviates from the color it should be [5].

From the results of the analysis of the organoleptic data, it was found that the treatment of vacuum packaging and cold storage did not significantly affect the aroma of chicken 'Urutan' during storage. The assessment of 15 panelists stated that the aroma "Urutan" of chicken until 50 days of storage was still normal, namely the distinctive aroma of "Urutan" of chicken, this aroma was obtained because there was a frying process that gave off a delicious, savory aroma due to the addition of complete spices ("base genep") on chicken meat. Up to 50 days of cold storage with vacuum or non-vacuum packaging there has not been any deviation in the aroma of the chicken "Urutan" even though from the nutritional value there has been a change in fat 
to free fatty acids and glycerol, which indicates a deterioration in quality but is still small so that odor has not occurred (usually become rancid).

Aroma is one of the parameters in determining the quality of a food product. A distinctive aroma can be felt by the sense of smell depending on the constituent ingredients and ingredients added to the food. Thus aroma can directly influence consumer interest in trying a food product. Aroma in food ingredients can be generated by volatile components, but these volatile components can be lost during the processing process, especially heating. In general, the delicacy of food is determined by aroma, so the food industry considers it very important to carry out an aroma test because it can quickly give the results of evaluating whether the product is preferred or not [4].

From the results of the organoleptic data analysis, it was found that the treatment of vacuum packaging and cold storage did not significantly affect the texture of the 'Urutan' of chickens during storage. The evaluation of 15 panelists stated that the texture or shape of the "Urutan" of chickens up to 50 days of storage was still normal, namely being elliptical. This shape is obtained because there is a process of inserting the dough into the sleeve (casing made from collagen). Up to 50 days of cold storage with vacuum or non-vacuum packaging there has not been any texture deviation in the "Urutan" of the chicks. The texture is still solid and compact.

Texture is sensing associated with touch or touch. Texture is a very important characteristic for products. The assessment of the texture comes from the touch by the skin surface, usually using the fingertips so that the texture of a material can be felt. Textures include hard, smooth, rough, oily and moist [4].

From the results of the analysis of the organoleptic data, it was found that the treatment of vacuum packaging and cold storage did not significantly affect the taste of chicken 'Urutan' during storage. The assessment of 15 panelists stated that the taste of the "Urutan" of chickens until 50 days of storage was still normal, namely the taste of the "Urutan" of chicken. Up to 50 days of cold storage with vacuum or non-vacuum packaging there has not been any deviation in the taste of the "Urutan". The taste of chicken is still delicious and savory.

Taste is an important factor of food, assessment of taste shows consumer acceptance of a food product. Taste assessment is carried out using human senses, the occurrence of taste impressions is when a food ingredient is chewed in the mouth then hydrolyzed by enzymes from saliva which form derivative compounds that give a certain taste when it comes into contact with the nerve endings of the taste buds on the tongue papilla [5].

Several factors that influence taste include chemical compounds, temperature, concentration and the interaction of other taste components. The factors that determine a product is accepted or not by consumers in terms of taste. Although the other assessment parameters are good, if the taste is not liked, the product will be rejected by consumers [6].

\subsection{Microbiological Parameters}

From the results of the total microbial test (ALT) in Table 3, it was found that the treatment of the packaging method and cold storage time had a significant effect $(p<0.05)$ on the total microbes that grew on the "Urutan" of chickens.

Table 3.Total Microbial (ALT) Test Results

\begin{tabular}{ccccc}
\hline \multirow{2}{*}{ Treatment } & \multicolumn{2}{c}{ Deuteronomy } & \multirow{2}{*}{ amount } & \multirow{2}{*}{ Average } \\
\cline { 2 - 3 } & I & II & & \\
\hline V1P0 & $2,4, \mathrm{E}+02$ & $5,4, \mathrm{E}+02$ & 780,000 & 390,000 \\
V1P1 & $1,3, \mathrm{E}+02$ & $2.0, \mathrm{E}+02$ & 330,000 & 165,000 \\
\hline
\end{tabular}




\begin{tabular}{ccccc}
\hline V1P2 & $2,2, \mathrm{E}+03$ & $6,8, \mathrm{E}+02$ & 2880,000 & 1440,000 \\
V1P3 & $5,2, \mathrm{E}+02$ & $7,6, \mathrm{E}+02$ & 1280,000 & 640,000 \\
V1P4 & $6,3, \mathrm{E}+02$ & $6.5, \mathrm{E}+02$ & 1280,000 & 640,000 \\
V1P5 & $7,8, \mathrm{E}+02$ & $6,8, \mathrm{E}+02$ & 1460,000 & 730,000 \\
V2P0 & $8,4, \mathrm{E}+02$ & $7,2, \mathrm{E}+02$ & 1560,000 & 780,000 \\
V2P1 & $7.0, \mathrm{E}+02$ & $5.0, \mathrm{E}+02$ & 1200,000 & 600,000 \\
V2P2 & $8,4, \mathrm{E}+02$ & $7,8, \mathrm{E}+02$ & 1620,000 & 810,000 \\
V2P3 & $4,4, \mathrm{E}+03$ & $1,2, \mathrm{E}+03$ & 5600,000 & 2800,000 \\
V2P4 & $8.0, \mathrm{E}+03$ & $7,8, \mathrm{E}+03$ & 15800,000 & 7900,000 \\
V2P5 & $9.8, \mathrm{E}+03$ & $1,1, \mathrm{E}+04$ & 20800,000 & 10400,000 \\
& 29080,000 & 25510,000 & 54590,000 & 2274,583 \\
\hline
\end{tabular}

Table 4. Total Escerichia coli (APM / g) in the chicken "Urutan"

\begin{tabular}{cccc}
\hline \multirow{2}{*}{ Treatment } & \multicolumn{2}{c}{ Deuteronomy } & Averag \\
\cline { 2 - 3 } & I & II & \\
\hline V1P0 & $<3$ & $<3$ & $<3$ \\
V1P1 & $<3$ & $<3$ & $<3$ \\
V1P2 & $<3$ & $<3$ & $<3$ \\
V1P3 & $<3$ & $<3$ & $<3$ \\
V1P4 & $<3$ & $<3$ & $<3$ \\
V1P5 & $<3$ & $<3$ & $<3$ \\
V2P0 & $<3$ & $<3$ & $<3$ \\
V2P1 & $<3$ & $<3$ & $<3$ \\
V2P2 & $<3$ & $<3$ & $<3$ \\
V2P3 & $<3$ & $<3$ & $<3$ \\
V2P4 & $<3$ & $<3$ & $<3$ \\
V2P5 & $<3$ & $<3$ & $<3$ \\
\hline
\end{tabular}

From the table above, it can be seen that the packaging method affects the total microbial average value of the "Urutan" chicken. The total microbial Urutan of chickens ranged from 165 to 10,400 colonies / gram. The lowest total microbes were obtained from the treatment of vacuum packaging method with cold storage for 10 days (V1P1), namely 165 colonies per gram, while the highest total microbes were obtained from the treatment of the non-vacuum packaging method, namely 10,400 colonies per gram.

There was an increase in total microbes during cold storage in both the vacuum packed and non-vacuum packed chicken Urutans, but the increase was much higher in the non-vacuumpacked Urutan of chicken, this was because the non-vacuum packaging allowed oxygen and water vapor to enter and exit. Stimulate microbial growth during storage. The total microbes obtained from the results of this study when compared to the standard meat sausage (SNI 3820-01-2015) almost all of them met the requirements of less than 1000 colonies per gram (only the V1P2, V2P3, V2P4 and V2P5 treatments exceeded the standard). There are still microbes that grow in cold storage due to various factors, namely the type of microbes (there are some microbes that can grow at low temperatures), water activity, and the presence of oxygen.

The total Escerichia coli (APM / g) in chicken "Urutan" can be seen in Table 4. When compared with the quality standard of meat sausage, all treatment combinations meet SNI 3820-01-2015 standards which require Eschericia coli to be less than 3 AMP / g. From this data it can be said that the Urutan of the chicken was made with good sanitation and hygiene so that it is not contaminated with Escerichia coli, this means that the chicken Urutan is safe for consumption. 


\section{Conclusion}

From the research results, there are several things as follows:

- Vacuum Packaging and Cold Storage treatment does affect all test parameters

- The treatment of the packaging method has an effect on the fatty acid levels of "Urutan" chickens. The vacuum packed order of chicken contains lower fatty acids than the packaged by no means vacuum

- The treatment of storage time affects the fatty acid levels of "urutan" chickens, the longer storage time is the higher the free fatty acid content of "sequence" chickens.

- The vacuum packaging method integrated with cold storage can increase the shelf life of "urutan" chickens by up to 30 days

\section{Acknowledgments}

The author would like to thank the Chairman of the Yayasan Korpri Propinsi Bali, Rector of Warmadewa University, the Head of the Warmadewa University Research Institute, the Dean of the Faculty of Agriculture and colleagues who have provided all support in completing this research.

\section{Reference}

[1] W. R. Aryanta, "Technological Aspects of Traditional Balinese Food," Seminar on Balinese Traditional Food. Middle Traditional Food Study Center, 1998.

[2] I. W. S. Partama, N. S Antara, and L. P Wrasiati, "The Effect of Addition of Garlic and Time of Fermentation on Microbiological and Organoleptic Quality of Bebontot," Universitas Udayana, 2005.

[3] D. R. Daughter, I. K. P. S Antara, I. G Suardika, and I. G Sujana, "Improving the quality of production packaging for the Bali Home Industry Urutan for the Disability Group in Bengkala, Buleleng, Bali," J. of Bhakti Persada, vol. 2, no. 2, 2019.

[4] AOAC, "Official Methods of Analysis of the Association of Official Analytical Chemist," Washington DC, 1984.

[5] S. T. Soekarto, "Organoleptic Assessment. For the Food and Agricultural Products Industry," Jakarta: Bhratara Karya Aksara, 1985.

[6] F. G. Winarno, and Betty, "Damage to Food Materials and How to Prevent Them," Jakarta: Yudhistira, 1982 